\title{
Moral and scientific realism: essays in honor of Richard N. Boyd and Nicholas L. Sturgeon
}

\author{
Elizabeth S. Radcliffe
}

Published online: 1 March 2014

(C) Springer Science+Business Media Dordrecht 2014

The essays in this issue are presented in honor of philosophers Richard N. Boyd and Nicholas L. Sturgeon. This issue grew out of a conference held September 14-16, 2012, at Cornell University, to mark the occasion of their retirement from the Sage School of Philosophy at Cornell.

The theme of this special issue is realism in morality and in science. Boyd and Sturgeon are closely identified with the metaethical view known as "Cornell realism," a theory both philosophers have articulated, developed and defended throughout their careers. Boyd's and Sturgeon's moral realism involves a commitment to objective, mind-independent facts about morality. Moral facts are natural facts, but irreducible to non-moral natural facts. Boyd is also a prominent defender of scientific realism, the view that scientific theories yield knowledge of the world, including of the unobservables the theories concern. Both Boyd and Sturgeon have related interests in evolutionary biology and its implications for ethics. All of these topics are treated in the articles presented in this issue.

The 2012 Cornell conference was organized by Professors Karen Bennett, Jill North, and Erin Taylor, and the featured speakers were Simon Blackburn, Laura Franklin-Hall, Gilbert Harman, Terence Irwin, Peter Railton, Elliott Sober, and Sharon Street. Many of the conference papers are included here, along with three additional pieces by co-authors Marc Ereshefsky and Thomas A. C. Reydon, by Mark Fedyk, and by William FitzPatrick. I was very fortunate to have had Nick Sturgeon as my graduate mentor and adviser many years ago. I'm sure that Nick's and Dick's former students, along with their Cornell colleagues, feel equally fortunate to have been recipients of their wisdom over the years.

\footnotetext{
E. S. Radcliffe ( $\square)$

Department of Philosophy, The College of William \& Mary, P.O. Box 8795, Williamsburg, VA 23187-8795, USA

e-mail: eradcliffe@wm.edu
} 